\title{
WEED CONTROL IN LICORICE
}

\author{
M.J. HARTLEY
}

\author{
Lawn Road, R D 2, Hastings
}

\begin{abstract}
Weed control trials were conducted in newly planted and one year old licorice in Hawkes Bay in 1994-96. Licorice, planted as root segments, showed good tolerance to trifluralin, chlorpropham plus diuron, and cyanazine and metribuzin applied pre-emergence. It also tolerated bentazone early post-emergence and metribuzin at any stage post-emergence. Straw or sawdust mulches were also effective for weed control and established licorice shoots merged through the mulches.
\end{abstract}

Keywords: licorice, herbicide tolerance, weed control

\section{INTRODUCTION}

Licorice (Glycyrrhiza globra) is a perennial herb of the pea family. The deciduous stems grow rapidly in the spring reaching a height of 1-2 $\mathrm{m}$. During the summer, licorice produces extensive underground stolons up to $2 \mathrm{~m}$ long carrying numerous dormant buds. The licorice of commerce is obtained from the roots and stolon which are either peeled and dried or crushed and a paste extracted. It has been used as a pharmaceutical plant for thousands of years (Singh et al. 1984). Licorice contains $6.8 \%$ glycyrrhizin which is 50 times sweeter than sugar (Morton 1977). Licorice is widely used in cough syrups, and many other medicines but can produce adverse effects in people with heart ailments. It is also widely used in confectionery, soft drinks, cocoa, beer and toothpaste. Estimated annual world production of licorice roots is between 25,000 and 30,000 tonnes mainly from Middle East, India and China (Singh et al. 1984).

In New Zealand, licorice is under investigation as a potential export crop. Part of this investigation involves finding suitable weed control practices for New Zealand conditions. Herbicide tolerance trials were commenced at the Hawkes Bay Research Centre in 1994.

\section{METHOD}

In year 1 , licorice was propagated from stolon segments. Stolons dug in Canterbury were sent to Hawkes Bay in September 1994. These were cut into segments, approximately $10 \mathrm{~cm}$ long, each with a dormant bud, and kept moist in a cool store until planted $5 \mathrm{~cm}$ deep on 13.10.94. Nine stolon segments were planted in each plot on a $3 \times 3$ grid $50 \mathrm{~cm}$ apart. Plot size was $1.5 \times 1.5 \mathrm{~m}$.

Herbicides were applied by precision sprayer in 200 litre/ha at $210 \mathrm{kPa}$. Preemergence treatments were applied on 17.10.94 and early post-emergence treatments on 13.11.94 (see Table 1). All treatments were replicated three times in randomised blocks. An adjacent area was used to test trifluralin (Triflur 40) at 0,0.5,0.75 and 1.0 $\mathrm{kg} / \mathrm{ha}$, applied on 12.10 .94 , incorporated by rotary hoe with licorice planted on 17.10.94. Trifluralin treatments were not replicated but three licorice plots (nine plants) were placed on each trifluralin treatment.

Weeds were counted on the untreated plots on 10.11 .94 from two $25 \times 15 \mathrm{~cm}$ quadrates per plot. All plots were assessed visually, by two observers, for weed cover on a 0 - 10 scale ( 10 represented complete cover) on 23.11.94 after which the untreated plots were hoed to remove weeds. Licorice emergence was recorded periodically form 23.11.94 to 17.1 .95 and vigour assessed visually on a $0-10$ scale. Length of the best stem of each plant (generally only one) was measured on 8.12.94. 
As weed control was poor by December, salvage treatments were tested by overspraying plots with either bentazone (Basagran) $(1.0 \mathrm{~kg} / \mathrm{ha})$, cyanazine (Bladex) $(2.0 \mathrm{~kg} / \mathrm{ha})$ or metribuzin (Lenone DF) $(0.3 \mathrm{~kg} / \mathrm{ha})$ on 8.12 .94 . Weeds were reassessed as above on 21.12.94 and licorice height measured on 17.1.95.

In year 2 a new planting of licorice was made from stolon segments dug locally, 12 segments/plot, with a plot size of $1.5 \times 2.0 \mathrm{~m}$. Trifluralin $(1.0 \mathrm{~kg} / \mathrm{ha})$ was applied as a split plot treatment ( 2 replicates) with treatments shown in Table 2 replicated four times. All herbicides were applied as in year 1 .

Also in year 2, the licorice plots used in 1994-95 were graded on licorice vigour into five grades. These were then randomised to the eight treatments shown in Table 3 , with one replicate on each of the five licorice grades. The straw and sawdust mulches were laid approximately $10 \mathrm{~cm}$ thick. Because of the stoloniforous growth of licorice, plots became intermixed in year 2 but treatments and assessments were confined to the original plot areas and regrowth from the original crowns.

Weeds were assessed visually as above on 16.11 .95 and 29.12.95. Licorice emergence (new planting) was recorded and height measured on 6.11 .95 and all plots assessed visually for vigour on 6.12.95 and 19.1.96. All data was analysed by SAS analysis of variance programme.

\section{RESULTS}

In 1994, most effective weed control, in the order of $80-90 \%$ reduction in weeds, was given by metribuzin post-emergence, cyanazine and MCPB post-emergence and chlorpropham (Chloro-IPC) plus diuron (Karmex) pre-emergence (Table 1).

\section{TABLE 1: Weed control and licorice growth following pre and post-emergence herbicide treatments in 1994. Pre-emergence herbicide applied 17.10.94; post-emergence herbicide applied 13.11.94.}

\begin{tabular}{lccc}
\hline Treatment & Rate & Weed & Licorice \\
$(\mathrm{kg} \mathrm{ai} / \mathrm{ha})$ & score $^{1}$ & Vigour $^{2}$ & Height $(\mathrm{cm})$ \\
& 23.11 .94 & 23.11 .94 & 8.12 .94 \\
\hline
\end{tabular}

\begin{tabular}{lcccr}
\hline $\begin{array}{l}\text { Pre-emergence } \\
\text { untreated/hand weeded }\end{array}$ & & & & \\
cyanazine & 1 & 9.3 & 5.6 & 10.3 \\
cyanazine & 2 & 3.3 & 6.6 & 7.2 \\
chlorpropham & 3 & 6.3 & 6.6 & 10.3 \\
chlorpropham + diuron & $2+1$ & 2.0 & 8.0 & 12.3 \\
metribuzin & 0.3 & 2.7 & 6.8 & 15.0 \\
Post-emergence & 1 & 3.7 & 7.2 & 11.3 \\
cyanazine & $1+0.5$ & 1.7 & 3.9 & 10.3 \\
cyanazine + MCPB & 1 & 5.0 & 6.2 & 15.7 \\
bentazone & 2 & 4.7 & 7.7 & 11.7 \\
bentazone & $1+1$ & 7.0 & 6.2 & 12.3 \\
bentazone + MCPB & 0.3 & 1.0 & 4.8 & 8.3 \\
metribuzin & 1 & 6.0 & 6.8 & 12.0 \\
MCPB & 2 & 6.0 & 5.0 & 8.0 \\
MCPB & & 2.1 & 4.7 & 8.0 \\
LSD 5\% & & 3.4 & 3.2 \\
\hline
\end{tabular}

${ }^{1}$ Weed score $0=$ No weeds; $10=$ complete weed cover

${ }^{2}$ Licorice vigour $0=$ dead; $10=$ healthy

These treatments also resulted in good licorice growth as measured by early vigour and height in December. Licorice emergence was less than $50 \%$ overall, probably due to storage of the stolon segments before planting. The low emergence did not appear to be treatment related. One metribuzin plot, accidentally oversprayed with bentazone 
( $1 \mathrm{~kg} / \mathrm{ha})$, showed very good weed control and licorice growth. The weed population on untreated plots on 10.11 .94 was $\left(\mathrm{No} . / \mathrm{m}^{2}\right)$; scrambling speedwell (Veronica persica) 670, redroot (amaranthus spp.) 515, summer grass (Digitaria sanguinalis) 466, black nightshade (Solanum nigram) 178, horned oxalis (Oxalis corniculata) 109, oxtongue (Picris echioides) 89, sow thistle (Sunchus oleraceus) 62, mallow (Malva spp.) 53 and fathen (Chenopodium album) 18.

Of the "salvage" treatment applied in December 1994 metribuzin gave best weed control, reducing weed density by about $50 \%$, while cyanazine gave useful improvement but bentazone had little effect. Licorice height extension after re-treatment was; metribuzin $9.7 \mathrm{~cm}$, cyanazine $12.5 \mathrm{~cm}$ and bentazone $14.0 \mathrm{~cm}$.

In 1995 trifluralin gave some improvement in weed control without any detrimental effect on licorice growth (Table 2). All other treatments gave good initial weed control but only metribuzin followed by bentazone maintained weed control through December. This late application of bentazone had a severe initial effect on the licorice but the licorice had recovered by January. None of the treatments had any significant effect in licorice emergence or height measured on 6.11.95 (date not shown).

TABLE 2: Weed control and vigour of newly planted licorice following herbicide treatment in 1995.

\begin{tabular}{|c|c|c|c|c|}
\hline \multirow[t]{2}{*}{ Treatment } & \multirow{2}{*}{$\begin{array}{c}\text { Rate } \\
\text { (kg ai/ha) }\end{array}$} & \multirow{2}{*}{$\begin{array}{c}\text { Date } \\
\text { Applied }\end{array}$} & Weed score ${ }^{1}$ & Licorice vigour $^{2}$ \\
\hline & & & $16.11 .95 \quad 29.12 .95$ & $6.12 .95 \quad 19.1 .96$ \\
\hline
\end{tabular}

\begin{tabular}{|c|c|c|c|c|c|c|}
\hline \multicolumn{7}{|c|}{ Main Treatment } \\
\hline trifluralin & 1.0 & 26.9 .96 & 2.0 & 2.5 & 7.4 & 8.5 \\
\hline LSD 5\% & & & 0.8 & 1.0 & 0.4 & 0.9 \\
\hline \multicolumn{7}{|c|}{ Sub Treatments } \\
\hline untreated & & & 7.0 & - & 8.6 & 8.3 \\
\hline chlorpropham & 2 & 1.10 .95 & 2.1 & 6.9 & 9.8 & 7.8 \\
\hline+ diuron & 1 & 1.10 .95 & & & & \\
\hline metribuzin & 0.25 & 18.10 .95 & 0.9 & 5.3 & 9.5 & 9.3 \\
\hline metribuzin & 0.25 & 18.10 .95 & 0.7 & 1.8 & 2.0 & 7.6 \\
\hline+ bentazone & 2 & 29.11 .95 & & & & \\
\hline LSD $5 \%$ & & & 1.1 & 1.4 & 0.6 & 1.2 \\
\hline
\end{tabular}

${ }^{1}$ Weed score $0=$ No weeds; $10=$ Complete weed cover

${ }^{2}$ Licorice vigour $0=$ dead; $10=$ Healthy

Pre-emergence and post-emergence herbicide treatments applied to established licorice all gave useful initial weed control but not as good as the straw and sawdust mulches (Table 3). The sawdust gave the best lasting weed control as prostrate amaranth (Amaranthus deflexus) grew through the straw on some plots. Licorice vigour was affected by the late application of bentazone and to some extent metribuzin, but the plants had recovered by January with no significant difference in plant height in April (data not shown).

\section{DISCUSSION}

Licorice showed good tolerance to a number of "pea herbicides" such as trifluralin, cyanazine, chlorpropham plus diuron and metribuzin. In the first trial when bentazone was accidentally applied early post-emergence (licorice $0-10 \mathrm{~cm}$ tall) to a metribuzin plot, both weed control and licorice growth were superior to any other treatment. In the second year the treatment was included but the bentazone was applied when the licorice was $20-30 \mathrm{~cm}$ tall and it resulted in severe scorching of the licorice. Though the licorice recovered, the check was undesirable suggesting bentazone should be applied early post-emergence when the licorice is still growing from its root reserves rather than its leaves. Licorice appears to have a very high tolerance to 
metribuzin at any stage, making this treatment very useful providing black-nightshade is not a major weed.

TABLE 3: Weed control and vigour of established licorice following pre-and post-emergence herbicide treatments and mulches applied in 1995.

\begin{tabular}{|c|c|c|c|c|c|c|}
\hline \multirow[t]{2}{*}{ Treatment } & \multirow{2}{*}{$\begin{array}{c}\text { Rate } \\
\text { (kg ai/ha) }\end{array}$} & \multirow{2}{*}{$\begin{array}{c}\text { Date } \\
\text { Applied }\end{array}$} & \multicolumn{2}{|c|}{ Weed score ${ }^{1}$} & \multicolumn{2}{|c|}{ Licorice vigour $^{2}$} \\
\hline & & & 16.11 .95 & 29.12 .95 & 6.12 .95 & 19.1 .96 \\
\hline untreated & & & 6.0 & $4.4^{3}$ & 8.8 & 8.4 \\
\hline \multicolumn{7}{|l|}{ Pre-emergence } \\
\hline chlorpropham & 2 & 13.9 & 2.0 & 2.6 & 9.4 & 8.4 \\
\hline+ diuron & 1 & & & & & \\
\hline cyanazine & 2 & & 2.2 & 3.4 & 9.0 & 8.8 \\
\hline cyanazine & 2 & 13.9 & 2.2 & 3.4 & 9.2 & 8.0 \\
\hline+ metribuzin & 0.5 & & & & & \\
\hline metribuzin & 0.5 & 13.9 & 1.4 & 2.6 & 9.0 & 9.2 \\
\hline \multicolumn{7}{|c|}{ Post-emergence } \\
\hline metribuzin & 0.5 & $18.10+29.11$ & 1.2 & 1.8 & 7.2 & 8.8 \\
\hline metribuzin & 0.5 & $18.10+29.11$ & 2.1 & 2.8 & 4.2 & 7.6 \\
\hline+ bentazone & 2 & 29.11 & & & & \\
\hline straw & & 1.10 & 0.2 & 2.4 & 9.4 & 7.6 \\
\hline sawdust & & 28.9 & 0 & 0.2 & 8.4 & 8.6 \\
\hline LSD $5 \%$ & & & 2.2 & 1.9 & 1.8 & NS \\
\hline
\end{tabular}

${ }^{1}$ Weed score $0=$ no weeds; $10=$ complete weed cover

${ }^{2}$ Licorice vigour $0=$ dead; $10=$ healthy

${ }^{3}$ Metribuzin (0.5 kg/ha) applied 29.11.95

None of the treatments tested gave full season weed control but once established licorice should be able to suppress weeds after December. The plant puts all its spring growth into foliage and established stands should have full canopy by December. After that date, licorice growth goes into stolon development. The top growth of licorice dies off in winter allowing the use of desiccant treatments. Pre-emergence use of chlorpropham plus diuron, cyanazine or early post-emergence use of metribuzin and/or bentazone should maintain weed control until the licorice canopy fills in, thus suppressing harmful weed growth.

This work suggests the best treatment for newly planted licorice would be trifluralin $(1.0 \mathrm{~kg} / \mathrm{ha})$ followed by chlorpropham plus diuron, cyanazine or metribuzin, applied pre-emergence, depending on weed spectrum. Metribuzin and bentazone could be used post-emergence but bentazone will scorch licorice when the leaves are fully expanded.

\section{ACKNOWLEDGEMENTS}

I would like to acknowledge funding from the N.Z. Institute for Crop \& Food Research Ltd and the use of their land and facilities to conduct this research. I thank Heather Martin for assistance with the trials.

\section{REFERENCES}

Morton, J.F., 1977. Licorice. Pp. 155-159. In: Major Medicinal Plants: Botany, Culture and Uses. Charles C. Thomas, U.S.A.

Singh, A.K., Sharma, A., Kumar, P. and Virmani O.P., 1984. Cultivation and utilization of liquorice (Glycyrrhiza glabra L.): A review. Crompa, 6 (2) 98-105. 